\title{
BRITISH SOCIETY OF
}

\section{ANIMAL PRODUCTION}

\section{Report of Proceedings}

Second Meeting, 24th October, I944

General Topic :

THE BRITISH SHEEP INDUSTRY

Joint Meeting with Institute for the Study of Animal Behaviour 25th October, 1944

General Topic:

\section{ANIMAL BEHAVIOUR}

PUBLISHED BY THE SOCIETY

Price $4 /-$, post free to Non-Members on application to the Secretary-Treasurer 
PRINTED IN GREAT BRITAIN BY HEADLEY BROTHERS IO9 KINGSWAY, LONDON, W.C.2; AND ASHFORD, KENT 


\section{Meetings, 24TH AND 25TH OGtober, 1944 HELD AT}

The London Sahool of Hygiene and Tropical Medicine

These meetings consisted of: an ordinary meeting of the British Society of Animal Production, on 24th October ; a joint meeting with the Institute for the Study of Animal Behaviour, on the morning of $25^{\text {th }}$ October ; and an ordinary meeting of the Institute for the Study of Animal Behaviour, on the afternoon of $25^{\text {th }}$ October, to which members of the Society were invited.

By arrangement with the Institute the papers and discussions at the third meeting are included in this publication.

British Society of Animal Institute for the Study of Production, Animal Behaviour,

Secretary-Treasurer :

Dr. J. E. Nichols, Hon. Secretary:

Imperial Bureau of Animal Professor A. N. Worden, Breeding and Genetics, King's Buildings. West Mains Road, University College of Wales, Aberystwyth.

Edinburgh, 9 . 